\title{
MAKALAH \\ RUANG LINGKUP ANTROPOLOGI HUKUM
}

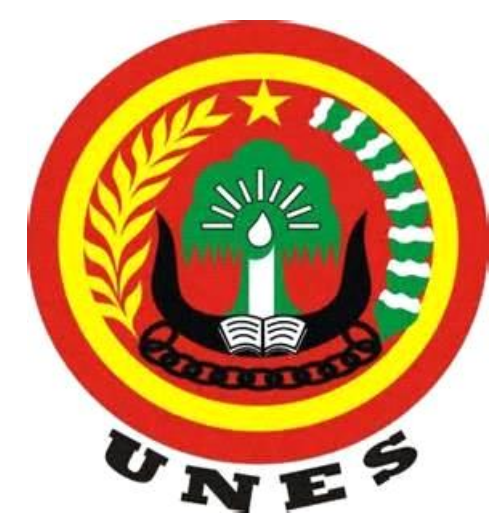

DISUSUN OLEH :

\section{HARRY SALAM}

harry.salam@pegadaian.co.id

BP : 2010003600294

PROGRAM STUDI ILMU HUKUM

FAKULTAS ILMU HUKUM

UNIVERSITAS EKASAKTI

PADANG

2021 


\section{A. PENDAHULUAN}

Antropologi sebagai disiplin ilmu terus berkembang, tidak hanya pada tataran teoritis tetapi juga sebagai ilmu terapan yang mampu memberikan masukan bagi para pembuat keputusan dalam menentukan kebijakan pembangunan. Di Indonesia, perkembangan antropologi sebagai disiplin ilmu yang dipelajari para mahasiswa di perguruan tinggi masih tergolong baru. Salah satu tokoh penting dalam perkembangan antropologi di Indonesia adalah Koentjaraningrat, sehingga dapat dikatakan bahwa ia merupakan bapak antropologi di Indonesia (Suparlan, 1988). Sebagai tokoh sentral di Indonesia, Koentjaraningrat telah meletakkan dasar-dasar antropologi Indonesia. Beberapa tugas yang berhasil diembannya adalah 1) mengembangkan prasarana akademis ilmu antropologi; 2) mempersiapkan dan membina tenaga-tenaga pengajar dan tenaga ahli di bidang antropologi; dan 3) mengembangkan bahan pendidikan untuk pembelajaran bidang antropologi (Masinambow, 1997). Sebagai disiplin ilmu, antropologi merupakan kajian yang multidisipliner yang berupaya mengkaji aspek manusia secara menyeluruh (holistik).

Secara historis, antropologi berkembang dari suatu deskripsi hasil-hasil laporan perjalanan para penjelajah dan penjajah tentang kehidupan manusia di daerah yang disinggahi para penjelajah, atau kehidupan salah satu suku bangsa yang tinggal di daerah jajahan. Deskripsi tersebut dikenal dengan nama etnografi. Dalam perjalanannya kemudian, antropologi berkembang sebagaimana keberadaannya sekarang baik di negara-negara Eropa Barat, Amerika maupun di Asia. Beberapa cabang antropologi yang dikenal secara luas saat ini adalah antropologi fisik atau biologi, antropologi sosial, dan antropologi budaya. Di sisi yang lain, antropologi juga merupakan bidang ilmu terapan sehingga hasil kajiannya dapat dimanfaatkan sebagai masukan dalam pengambilan keputusan untuk keperluan pembangunan, terutama 
dalam pembangunan sosial budaya, seperti antropologi pembangunan, antropologi kesehatan, antropologi ekonomi, dan sebagainya. Adapun hal hal yang akan dibahas pada makalah ini adalah bagaimana kita mengetahui manfaat - manfaat apa saja yang terkandung di dalam Ruang lingkup antropologi hukum, bagaimanakah pengertian Peran/peranan mengembangkan prasarana akademis ilmu antropologi dalam ruang lingkup antropologi hukum, bagaimanakah pengertian mempersiapkan dan membina tenaga-tenaga pengajar dan tenaga ahli di bidang antropologi ruang lingkup antropologi hukum, dan bagaimanakah pengertian mengembangkan bahan pendidikan untuk pembelajaran bidang antropologi Nilai dalam ruang lingkup antropologi hukum. Kemudian, tujuan dari makalah ini adalah memberikan gambaran teori mengenai Peran, Status, Nilai, Norma, dan juga Budaya/kebudayaan dalam kaitannya dengan masyarakat sebagai sasaran ilmu Sosiologi, sebagai arahan agar saya sebagai mahasiswa dapat mengkorelasikan hubungan antara teori Peran, Status, Nilai, Norma dan Budaya/kebudayaan dengan kehidupan masyarakat di kehidupan yang nyata. 


\section{B. PEMBAHASAN}

1. Pengertian Ruang Lingkup Antropologi

Pada penjelasan awal ini Anda akan menemukan beberapa pengertian tentang antropologi yang disampaikan oleh beberapa ahli. Dengan demikian Anda dapat memperoleh pemahaman umum tentang apa itu antropologi dan apa yang dipelajari oleh antropologi. Bagaimana Anda sudah siap untuk belajar? Jangan lupa Anda sediakan alat-alat tulis sehingga Anda dapat memberi tanda pada BMP ini atau menulis kembali konsep, istilah atau definisi yang dianggap penting pada selembar kertas atau buku. Dengan demikian, Anda akan menjadi lebih mudah untuk mempelajarinya kembali, sehingga akan selalu teringat dan dapat memperoleh pemahaman tentang antropologi dengan baik. 1. Pengertian Antropologi Sebelum Anda mempelajari lebih jauh tentang antropologi maka Anda terlebih dulu harus mengetahui pengertian dari antropologi. Nah, sekarang kita mulai dengan arti dari kata "Antropologi".

Antropologi adalah sebuah ilmu yang mempelajari makhluk manusia (anthropos). Secara etimologi, antropologi berasal dari kata anthropos berarti manusia dan logos berarti ilmu. Dalam antropologi, manusia dipandang sebagai sesuatu yang kompleks dari segi fisik, emosi, sosial, dan kebudayaannya. Antropologi sering pula disebut sebagai ilmu tentang manusia dan kebudayaannya. Antropologi mulai banyak dikenal orang sebagai sebuah ilmu setelah diselenggarakannya simposium pada tahun 1951 yang dihadiri oleh lebih dari 60 tokoh antropologi dari negara-negara di kawasan Ero-Amerika (hadir pula beberapa tokoh dari Uni Soviet). Simposium yang dikenal dengan sebutan International Symposium on Anthropology ini telah menjadi lembaran baru bagi antropologi, terutama terkait dengan publikasi beberapa hasil karya antropologi, seperti buku yang berjudul "Anthropology Today" yang di redaksi oleh A.R. Kroeber (1953), “An Appraisal of Anthropology Today” yang di redaksi 
oleh S. Tax, dkk. (1954), "Yearbook of Anthropology" yang diredaksi oleh W.L. Thomas Jr. (1955), dan "Current Anthropology" yang di redaksi oleh W.L. Thomas Jr. (1956). Setelah simposium ini, antropologi mulai berkembang di berbagai negara dengan berbagai tujuan penggunaannya. Di beberapa negara berkembang pemikiranpemikiran antropologi mengarah pada kebutuhan pengembangan teoritis, sedangkan di wilayah yang lain antropologi berkembang dalam tataran fungsi praktisnya. Pengertian lainnya disampaikan oleh Harsojo dalam bukunya yang berjudul "Pengantar Antropologi" (1984). Menurut Harsojo, antropologi adalah ilmu pengetahuan yang mempelajari umat manusia sebagai makhluk masyarakat. Menurutnya, perhatian antropologi tertuju pada sifat khusus badani dan cara produksi, tradisi serta nilai-nilai yang akan membedakan cara pergaulan hidup yang satu dengan pergaulan hidup yang lainnya.

Sementara itu Koentjaraningrat dalam bukunya yang berjudul "Pengantar Antropologi I " (1996) menjelaskan bahwa secara akademis, antropologi adalah sebuah ilmu tentang manusia pada umumnya dengan titik fokus kajian pada bentuk fisik, masyarakat dan kebudayaan manusia. Sedangkan secara praktis, antropologi merupakan sebuah ilmu yang mempelajari manusia dalam beragam masyarakat suku bangsa guna membangun masyarakat suku bangsa tersebut.

\section{Perkembangan Antropologi}

Sebagaimana diungkapkan Koentjaraningrat bahwa kita harus mempelajari ilmu-ilmu yang menjadi pangkal dari antropologi dan bagaimana garis besar proses perkembangannya yang mengintegrasikan ilmu-ilmu pangkal tersebut, maka pada bahasan berikut akan diuraikan perkembangan antropologi. Dari bahasan ini Anda akan bisa melihat bahwa perkembangan antropologi terkait erat dengan dinamika masyarakat. Latar Belakang Lahirnya Antropologi Antropologi pada masa 
perkembangan awalnya tidak dapat dipisahkan dengan karya-karya para penulis yang mencatat gambaran kehidupan penduduk atau suku bangsa di luar Eropa. Pada saat itu, kehidupan penduduk di luar Eropa dipandang menarik oleh para penjelajah, para penjajah, atau para misionaris karena perbedaan cara hidup antara masyarakat Eropa dengan masyarakat di luar Eropa. Oleh karenanya, mereka bukan saja menulis tentang perjalanan atau yang terkait dengan tugasnya tetapi juga melengkapinya dengan deskripsi tentang tata cara kehidupan masyarakat yang mereka temui. Deskripsi ini kemudian dikenal dengan sebutan etnografi. Beberapa tulisan karya mereka akan dipaparkan pada uraian berikut. Tulisan Herodotus, seorang bangsa Yunani yang dikenal pula sebagai Bapak sejarah dan etnografi, mengenai bangsa Mesir merupakan tulisan etnografi yang paling kuno. Tulisan-tulisan etnografi pada masa awal masih bersifat subyektif, penuh dengan prasangka dan bersifat etnosentrisme. Etnosentrisme adalah sebuah pandangan atau sikap di mana suku bangsa sendiri dianggap lebih baik dan dijadikan ukuran dalam melihat baik buruknya karakter suku bangsa lainnya. Orang Yunani pada masa itu menganggap bahwa suku-suku bangsa selain orang Yunani seperti orang Mesir, Libia dan Persia termasuk ke dalam suku bangsa yang masih setengah liar dan belum beradab. Pandangan seperti ini juga tersirat dalam tulisan Heredotus yang mendeskripsikan suku bangsa Mesir tersebut.

Pada jaman Romawi kuno terdapat pula beberapa hasil karya etnografi mengenai kehidupan suku bangsa Germania dan Galia yang ditulis oleh Tacitus dan Caesar. Sebagai seorang perwira yang memimpin perjalanan tentaranya sampai ke Eropa Barat, Caesar menulis etnografinya secara sistematis seperti halnya bentuk laporan seorang perwira. Sedangkan Tacitus menulis etnografinya dengan gaya bahasa yang mengungkap perasaan dan kegalauannya tentang kehidupan yang terdapat di ibukota kerajaan Roma. Pencatat etnografi yang cukup terkenal adalah 
Marco Polo (1254-1323). Ia mengembara dengan keluarga besarnya ke daerah Asia Timur dan sempat menetap di istana Khu Bilai Khan. Di sini ia melihat beberapa kebiasaan yang dianggapnya aneh, yaitu penggunaan uang yang terbuat dari kertas dan diberi cap serta ditandatangani di mana uang tersebut mempunyai bermacammacam nilai. Marco Polo juga pernah singgah di daratan Indonesia (yang diketahui dari tulisannya), di mana ia pernah singgah di beberapa pelabuhan dari semenanjung Malaya hingga menelusuri Pulau Sumatra, di antaranya adalah singgah ke di pelabuhan Perlec (dalam bahasa Aceh) atau Peureula atau Perlak (dalam bahasa Melayu). Marco Polo menceritakan kehidupan di kota pelabuhan ini di mana pedagang dari India dan penduduk pribuminya menganut agama Islam sedangkan penduduk yang ada di pedalaman masih mengerjakan hal-hal yang haram. Tulisan etnografi yang dianggap lebih baik dan obyektif justru adalah buah tangan dari seorang padri berbangsa Prancis yaitu Yoseph Francis Lafitau (1600-1740). Ia mencoba membandingkan antara kebiasaan dan tata susila orang Indian yang hendak dinasranikan dengan adat istiadat bangsa Eropa kuno. Hasilnya, ia beranggapan bahwa bangsa primitif (Indian) tidak dilihatnya sebagai manusia yang aneh. Akan tetapi karena bahan yang diperbandingkannya sangat terbatas maka pandangannya tentang perbandingan ini pun sangat terbatas. Ahli etnografi, dalam arti yang modern (Harsojo, 1984), adalah Jens Kreft, seorang guru besar pada akademi di Soro. Ia menulis sebuah buku berjudul "Sejarah Pendek tentang Lembaga-lembaga yang Terpenting, Adat dan Pandangan-pandangan Orang Liar” 1760. Jens Kreft awalnya adalah seorang ahli filsafat, di mana ia tidak sependapat dengan pandangan Rousseau tentang manusia. Pandangan Jens Kreft tentang manusia lebih dianggap mewakili pandangan sebagai seorang ahli etnologi daripada pandangan para ahli filsafat. Tulisan etnografinya adalah mengenai dua suku bangsa Indian, Lule dan Caingua, di 
Amerika Selatan, yang pada awalnya diduga mempunyai kebudayaan yang rendah. Ternyata dugaannya itu salah. Ia pun dipandang sebagai orang pertama yang menulis etnografi secara lengkap yaitu dengan memperhatikan aspek pertumbuhan ekonomi, masyarakat, agama dan kesenian.

\section{Karakteristik Kajian Antropologi}

Sejak lama manusia, terutama para ahli ilmu sosial dan para filsuf, mempertanyakan "sebenarnya siapa manusia itu, dari mana manusia itu berasal, dan mengapa berperilaku seperti yang mereka lakukan". Pertanyaan tersebut terus berkumandang sampai metode ilmiah ditemukan dan menjadi salah satu cara dalam menemukan sesuatu. Antropologi yang menjadi salah satu ilmu yang terkait dengan itu berusaha juga untuk menjawab pertanyaan di atas. Sebelumnya, masyarakat memperoleh jawaban atas pertanyaan di atas dari mite (myth) dan cerita rakyat (folklore) yang diturunkan dari generasi ke generasi. Mite atau legenda merupakan unsur sastra yang masih dipercayai kebenarannya oleh para pendukung sastra tersebut. Mereka percaya saja pada apa yang diceritakan secara turun-temurun oleh orang tua atau nenek kakek mereka. Setiap suku bangsa memiliki kepercayaan sendiri atas siapa sebenarnya manusia itu, dari mana mereka berasal, dan mengapa mereka berperilaku seperti yang mereka lakukan. Orang yang tinggal di pegunungan biasanya beranggapan bahwa nenek moyang mereka berasal dari puncak gunung (bagian atas) yang memang sulit dijangkau oleh manusia biasa. Sedangkan bagi orang-orang yang tinggal di sekitar laut seperti para nelayan biasanya beranggapan bahwa nenek moyang mereka berasal dari laut yang paling dalam. Antropologi sebagai sebuah ilmu, sudah sekitar 200 tahun yang lalu berupaya mencari jawaban atas pertanyaan di atas. Antropologi kemudian dikenal sebagai ilmu yang mempelajari makhluk manusia (humankind) di mana pun dan kapan pun. Para antropolog mempelajari homo sapiens, 
sebagai spesies paling awal, sebagai nenek moyang, dan sesuatu (makhluk) yang memiliki hubungan terdekat dengan makhluk manusia, untuk mengetahui kemungkinan siapa nenek moyang manusia itu, dan bagaimana mereka hidup (Haviland, 1991). Perhatian utama dari para antropolog adalah merupakan upaya mereka mempelajari manusia secara hati-hati dan sistematis. Beberapa orang menempatkan antropologi sebagai ilmu sosial atau ilmu perilaku. Akan tetapi di lain pihak beberapa orang mempertanyakan sejauh mana kajian antropologi dapat diakui sebagai ilmu pengetahuan (science). Apa sesungguhnya arti di balik kata ilmu pengetahuan atau science itu? Ilmu pengetahuan adalah suatu metode atau cara yang bersifat berpengaruh dan tepercaya guna memahami fenomena di dunia ini. Ilmu pengetahuan berupaya mencari penjelasan mengenai berbagai fenomena yang dapat teramati (observed) untuk menemukan prinsip-prinsip atau hukum-hukum yang berlaku universal atas fenomena tersebut (Haviland, 1999). Ada dua ciri mendasar dari ilmu pengetahuan, yaitu imajinasi (imagination) dan skeptisisme (skepticism). Imajinasi berhubungan dengan kemampuan berpikir untuk mengarahkan kita keluar dari ketidakbenaran, yaitu dengan cara mengusulkan hal-hal baru untuk menggantikan hal-hal yang lama atau ketidakbenaran itu. Skeptisisme adalah pemikiran yang membimbing kita untuk dapat membedakan antara sebuah fakta (fact) dan khayalan (fancy). Sebuah kebenaran yang dihasilkan melalui sebuah khayalan bukanlah ilmu pengetahuan. Ilmu pengetahuan membangun kebenaran berdasarkan pengkajian empiris melalui uji hipotesis, yang kemudian menghasilkan sebuah teori. 


\section{PENUTUP}

Sebuah kebenaran atau teori dalam ilmu pengetahuan bukanlah kebenaran absolut tetapi hanya sebagai sebuah pilihan kebenaran yang paling diakui tentang sebuah fenomena. Tanpa metode ilmiah suatu ilmu pengetahuan bukanlah ilmu, melainkan hanya suatu himpunan pengetahuan saja tentang berbagai fenomena baik alam ataupun masyarakat karena tidak berusaha untuk mencari kaidah hubungan antara satu gejala dengan gejala lainnya. Keseluruhan pengetahuan dapat diperoleh oleh para ahli di bidangnya masing-masing melalui tiga tahap yaitu, (1) tahap pengumpulan data, (2) tahap penentuan ciri-ciri umum dan sistem, serta (3) tahap verifikasi. Untuk bidang antropologi sosial atau budaya, tahap pengumpulan data merupakan peristiwa penting dalam upaya memperoleh informasi tentang peristiwa atau gejala masyarakat dan kebudayaan. Sebagai ilmu sosial yang relatif baru, antropologi juga mengikuti kaidahkaidah ilmu pengetahuan yang telah berkembang, terutama pendekatan yang berkembang dalam ilmu sosial.

Berawal dari filsafat, beberapa kajian yang lebih spesifik akhirnya memisahkan diri dan memproklamirkan diri sebagai ilmu baru. Bahkan spesifikasi kajian dari masing-masing ilmu tadi dianggap telah membelenggu diri untuk tidak menerima hasil pengkajian dari ilmu lain. Kondisi ini kemudian disadari merupakan gejala yang tidak baik, karena sangat tidak bermanfaat untuk memahami hakikat objek (masyarakat) yang sesungguhnya. Hakikat objek, perilaku sosial atau masyarakat hanya dapat dipahami secara menyeluruh dengan kajian berbagai bidang ilmu. J. Gillin mencoba menyatukan kembali beberapa pendekatan melalui beberapa ahli seperti ahli antropologi, sosiologi dan psikologi untuk membicarakan kemungkinan kerja sama antara ketiga bidang ilmu tersebut. 


\section{DAFTAR PUSTAKA}

Conrad, Philip Kottak. (1991). Anthropology: The Exploration of Human Diversity. Edisi ke 5. New York: McGraw-Hill, Inc. Harsojo. (1984).

Koentjaraningrat dan Antropologi di Indonesia. Jakarta: AAI dan Yayasan Obor Indonesia.

Pengantar Antropologi. Cetakan kelima. Jakarta: Penerbit Rineka Cipta Koentjaraningrat. (1996). Pengantar Antropologi I. Jakarta: Penerbit Rineka Cipta. Koentjaraningrat. (1982).

Sejarah Teori Antropologi. Jakarta: Penerbit Rineka Cipta. Masinambow, E.K.M. (1997).

Suparlan, Parsudi. (1988). Prof. Koentjaraningrat: Bapak Antropologi Indonesia. Makalah untuk menyambut purna kedinasan Koentjaraningrat. 